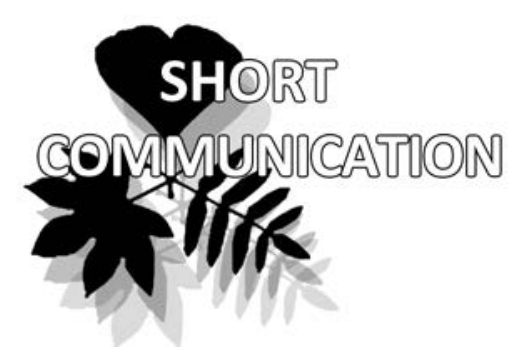

\title{
The estimation of relative DNA content in the genus Spiraea L., section Calospira C. Koch.
}

\author{
Vera A. Kostikova ${ }^{1}$, Mariya S. Voronkova ${ }^{1}$, Evgeny V. Banaev ${ }^{1}$ \\ \& Tatiana A. Poliakova ${ }^{2}$
}

Vera A. Kostikova ${ }^{1 *}$

e-mail: serebryakova-va@yandex.ru

Mariya S. Voronkova ${ }^{1}$

e-mail: bmc_87@mail.ru

Evgeny V. Banaev ${ }^{1}$

e-mail: alnus2005@mail.ru

Tatiana A. Poliakova ${ }^{2}$

e-mail: tat-polyakova@yandex.ru

${ }^{1}$ Central Siberian Botanical Garden SB RAS, Novosibirsk, Russia

${ }^{2}$ Vavilov Institute of General Genetics RAS, Moscow, Russia

* corresponding authors

Manuscript received: 15.02.2018

Review completed: 05.05.2018

Accepted for publication: 07.05.2018

Published online: 21.05.2018

\begin{abstract}
A B S T R A C T
The estimation of relative DNA content in cell nuclei in the genus Spiraea L. section Calospira C. Koch. from the Russian Far East is given for the first time. The cell nuclei were isolated from a leaf tissue. The relative intensity of fluorescence was measured by the nuclei stained with propidium iodide using flow cytometry. The values of relative DNA amounts in Spiraea differ significantly within a high statistical significance $(\mathrm{p}<0.001)$. It is revealed that the relative DNA content of S. betulifolia Pall. $(2 \mathrm{C}=0.91$ and $1.01 \mathrm{pg})$ is twice higher than those values in other species. The $S$. beawverdiana Schneid. $(2 \mathrm{C}=0.55$ and $0.57 \mathrm{pg})$ and the $S$. aemiliana Schneid. $(2 \mathrm{C}=0.45$ and $0.48 \mathrm{pg})$ are close to the amount of DNA they contain. Ke ywords: Spiraea betulifolia, Spiraea beauverdiana, Spiraea aemiliana, nuclear DNA amount, flow cytometry, DNA C-value
\end{abstract}

\section{P E 3 Ю M E}

Костикова В.А., Воронкова М.С., Банаев Е.В., Полякова Т.А. Оценка относительного содержания АНК у растений рода Spiraea L. секции Calospira C. Koch. методом проточной цитометрии. Впервые исследовано относительное содержание $\triangle \mathrm{HK}$ у растений рода Spiraea L. секции Calospira C. Koch., произрастающих в российской части ареала. ЯАра клеток выАелены из тканей мистьев. Относительная интенсивность флюоресценции измерена на ядрах, окрашенных йодидом пропидия, с помощью проточной цитометрии. Значения относительного содержания АНК у Spiraea Аостоверно отличаются ( $\mathrm{p}<0.001)$. Y S. betulifolia Pall. $(2 \mathrm{C}=0.91$ и 1.01 пикограмм $)$ относительное содержание $А$ ВК в Ава раза превышает значения у остальных видов. $S$. beawerdiana Schneid. $(2 \mathrm{C}=0.55$ и 0.57 пг) и $S$. aemiliana Schneid. $(2 \mathrm{C}=$ 0.45 и 0.48 пг) более близкие таксоны по содержанию $А$ НК

Кнючевые слова: Spiraea betulifolia, Spiraea beauverdiana, Spiraea aemiliana, относительное содержание АНК, проточная цитометрия
The studies on changes in the genome size of one species or closely related species of plants from different areas allow us to judge the evolutionary processes and their types as well as predict next steps of evolution (Marda at al. 2008). The genome size can be an informative marker in plant taxonomy at the species and subspecies level along as with chromosome numbers, morphological or anatomical features (Talluri \& Murray 2009).

The species in the section Calospira C. Koch. differ from all other species in the genus Spiraea L. by their inflorescences. The inflorescences make a broad complex corymbose or oval panicles. Some authors consider that this polymorphic group from the Calospira section is a single species - S. betulifolia Pall. (Nedoluzhko 1995). Other authors distinguish between 2 and 4 species in this section (Vorobyev 1968, Yakubov 1996, Koropachinsky \& Vstovskaya 2002). Within this section, Tzvelev (2008) identifies 3 species and 2 notospecies of hybridogenic origin. There are still many questions to understand the taxonomic status of closely related species $S$. betulifolia, $S$. beawverdiana Schneid. and S. aemiliana Schneid. This happens due to a different understanding of the volume of the species by different taxonomists and a choice of discriminant features on which to distinguish these species. The species $S$. betulifolia and $S$. beauverdiana growing on the territory of the Russian Far East are characterized by a high flexibility of morphological parameters (Kostikova \& Polyakova 2014). These species have intermediate forms in places of joint growth in Khabarovsk Krai, Sakhalin and the Republic of Sakha (Yakutia). The S. betulifolia also grows in China and Japan, and the $S$. beauverdiana - in China, Korea and North America (Koropachinsky \& Vstovskaya 2002). In the study of the variability of morphological characters it was confirmed that the species $S$. beauverdiana and $S$. betulifolia differ from each other by the following characteristics: a dense pubescence of pedicel and follicle, a curved position of follicle rostrum. The qualitative composition of phenolic compounds in water-ethanol extracts of leaves of the Spiraea were also defined as species-specific. The $S$. beawerdiana and $S$. betulifolia slightly differ from each other in morphometric morphological characteristics (Kostikova \& Polyakova 2014). The $S$. aemiliana has a low height of the shrub to $30 \mathrm{~cm}$ and has rounded leaves. In terms of its habitus the 
S. aemiliana is closer to the $S$. beawerdiana. The $S$. aemiliana also grows in Japan (Vorobyev 1968).

The purpose of this study is to compare the relative DNA amounts in cell nuclei of plants in the genus Spiraea section of Calospira.

The materials for the study were fresh leaves of three species of the genus Spiraea section of Calospira, collected in 2017 from plants introduced at the experimental plot of land of the Laboratory of Phytochemistry of the Central Siberian Botanical Garden SB RAS (CSBG) and from plants growing in native populations (Table 1). Almost all studied plants are brought from the native populations; some of them are grown from seeds collected also in the native populations. This study included specimens which morphological description corresponds to the species identifying specific differences in the relative content of DNA. For each species, 10 plants from each of two populations were examined. All tests were carried out in 3 replicates.

The flow-cytometric measurements were run in the Laboratory of Dendrology in the CSBG. The content of plant DNA was determined by a flow cytometry with staining isolated nuclei by propidium iodide (PI). The analysis was carried out on a CyFlowSpace device (Germany, Sysmex Partec) with a laser radiation source of $532 \mathrm{~nm}$. The fresh leaves of Solanum lycopersicum cv. 'Stupice' (2C DNA content $=1.96$ $\mathrm{pg}$ ) were used as an internal standard which seeds were obtained from the Centre of the Plant Structural and Functional Genomics of the Institute of Experimental Botany AS CR, Olomouc, Czech Republic (Doležel et al. 1992).

A part of the fresh leaf of a $0.5 \mathrm{~cm}^{2}$ size was ground using an acute blade along with an appropriate amount of internal standard in $500 \mu \mathrm{l}$ of a cooled commercial buffer (Nuclei Extraction Buffer) (Germany, Sysmex Partec) according to the manufacturer's protocol in plastic Petri dishes adding polyvinylpyrrolidone (MB 29,000) (USA, Sigma-Aldrich). The samples incubation was carried out at room temperature for 2 minutes. The samples were filtered through the Cellecrics Partec 50 micron (Germany, Sysmex Partec) and then $2 \mathrm{ml}$ of a staining solution were added containing another commercial buffer (Staining Buffer) (Germany, Sysmex Partec), PI (50 $\mu \mathrm{g} / \mathrm{ml})$ and RNAse A (50 $\mu \mathrm{g} /$ $\mathrm{ml}$ ). The incubation (staining) was performed at room temperature in a dark place for 40 minutes. The prepared samples were stored in a refrigerator for no more than 4 hours.
15,000 events were collected for each sample. The DNA 2C value content was calculated on a linear relationship between fluorescent signals from the stained nuclei of the internal standard and studied specimens.

The received data is carried out with the help of the software Statistica 6.0. (StatSoft, Inc. 1984-2001). The taxa differences by the relative DNA amounts were studied by a nonparametric variance analysis (ANOVA) using the Kraskel-Wallis criterion.

The nuclear DNA content of plants of the genus Spiraea section Calospira growing in the Russian Far East is determined for the first time by the flow cytometry method according to the fluorescence relative intensity (Table 1). The nuclear DNA content varies from $0.45 \mathrm{pg}$ in the $S$. aemiliana to $1.01 \mathrm{pg}$ in the $S$. betulifolia.

The colored nuclei generate histograms of the relative DNA content of the sample and the comparative standard (Fig. 1). The histograms of the flow cytometry represent two dominant peaks corresponding to the sample G0/G1 nuclei and the reference standard as well as a peak corresponding to the standard G2 nuclei.

The relative DNA (2C) content in angiosperms changes from 0.22 to $254.8 \mathrm{pg}$ (Leitch et al. 2005). The variability of the relative DNA content in the Rosaceae family is low. The subfamily Spiraeoideae plant genome size is referred to the smallest among angiosperms (Dickson et al. 1992). The nuclear DNA content values of the genus Spiraea species are comparatively small and according to the gradation of Leitch et al. (2005) fall into the category of "very small": S. chamaedryfolia $2 \mathrm{C}=0.90 \mathrm{pg} ; S$. chinensis $0.40 ;$ S. crenata 0.45 ; S. pubescens 0.95 ; S. wilsonii 1.60; S. nipponica 1.75 and S. sargentiana 1.85 (Dickson et al. 1992, Siljak-Yakovlev et al. 2010, Bennett \& Leitch 2012). The range of relative DNA content in plants of the genus Spiraea, section Calospira is within the values previously recorded for Spiraea. A comparative analysis of the relative DNA content of the studied Spiraea revealed the facts that the values differ at a high statistical significance $(\mathrm{p}<0.001)$ (Fig. 2). The S. betulifolia occupies plain and low mountain forest lands in middle and southern regions of the Asian Russia. The $S$. beanaverdiana acquired new adaptive features (dense pubescence of organs, a tendency to a general reduction in plant size) that allow it to settle in upland alpine tundra areas of the range northern part (Koropachinsky \& Vstovskaya 2002, Kostikova \& Polyakova

Table 1. The nuclear DNA content and the site of material collection of close species of the genus Spiraea, section Calospira (standard Solanum bropersicum cv. 'Stupice' (2C DNA content $=1.96$ pg) (Doležel et al. 1992)

\begin{tabular}{|c|c|c|c|}
\hline $\begin{array}{l}\text { Sample } \\
\text { № }\end{array}$ & Sites of material collection & $\begin{array}{c}\text { 2C DNA content, } \\
\text { pg, } \pm \text { SD } * * *\end{array}$ & $\begin{array}{l}1 \mathrm{C}^{* * * *} \text { (genome } \\
\text { value), (Mbp) }\end{array}$ \\
\hline \multicolumn{4}{|c|}{ S. betulifolia } \\
\hline 1 & Kunashir Island, Golovnino village environs & $1.01 \pm 0.01$ & 493.89 \\
\hline 2 & Primorsky Krai, Anisimovka village environs, Livadia Range, Mount Litovka * & $0.92 \pm 0.01$ & 449.88 \\
\hline \multicolumn{4}{|c|}{ S. beauverdiana } \\
\hline 3 & Khabarovsky Krai, Kur-Urmia Range & $0.55 \pm 0$ & 268.95 \\
\hline 4 & Republic of Sakha (Yakutia), Maly Nimnyr settlement environs** & $0.57 \pm 0.007$ & 278.73 \\
\hline \multicolumn{4}{|c|}{ S. aemiliana } \\
\hline 5 & Kunashir Island, Golovnino volcano caldera & $0.48 \pm 0.005$ & 234.72 \\
\hline 6 & Sakhalin Island, Chekhov peak & $0.45 \pm 0.01$ & 220.05 \\
\hline
\end{tabular}

Note: * plant grown of seeds; ** natural material; *** SD - standard deviation (Std. Dev.); **** 1 pg of DNA = 978 Mbp (Doležel et al. 2003) 

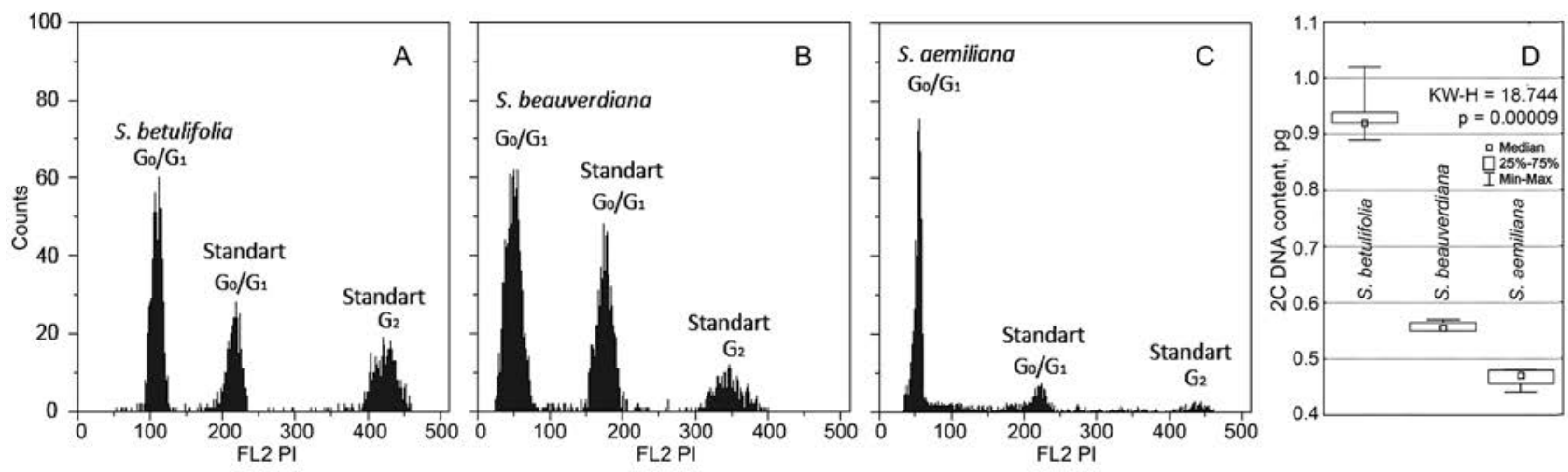

Figure 1 Histogram of PI fluorescence intensity (A-C): S. betulifolia (A); S. beauverdiana (B); S. aemiliana (C). A standard is Solanum lycopersicum cv. 'Stupice' (2C DNA content $=1.96$ pg) (Doležel et al. 1992) and the relative nuclear DNA content (D)

2014). In the places of joint growth these species are not clearly separated from each other, perhaps these taxa represent different ecotypes of the same species (Svyazeva 1967). The relative DNA content in the S. betulifolia is the higher 0.91 and $1.01 \mathrm{pg}$ (Table 1, Fig. 2). The values of the relative DNA content of the $S$. beauverdiana are almost twice lower than in the $S$. betulifolia -0.55 and $0.57 \mathrm{pg}$. The southeast Asia is the center of Spiraea distribution. The species were dispersed northward, from more to less favorable climatic conditions, so it is possible to trace the tendency of decreasing the relative DNA content of plants because of habitat conditions deterioration. That means that the relative DNA content in plants of the genus Spiraea, section Calospira decreases northward.

The $S$. aemiliana occurs on the Russia's island part - the Kurils and Sakhalin Islands. The nuclear DNA content of this species is the lowest -0.45 and $0.48 \mathrm{pg}$. The $S$. aemiliana differs from $S$. betulifolia even more than twice and it is closer to the $S$. beawverdiana by the relative DNA content. As the population No. 1 of S. betulifolia and the populations No. 5 of $S$. aemiliana are located relatively close each other on the Kunashir Island, they grow under the same climatic conditions, it is likely that differences in DNA content are related to the species taxonomic position.

Within the same chromosomal composition, the nuclear DNA content can differ significantly between various taxa (species) within the genus (Talluri \& Murray 2009). There are diploids and polyploids: tetraploids, octoploids among the genus Spiraea plants (Zhukova 1980, Oginuma et al. 2004, Polyakova \& Muratova 2015, http://www.tropicos. org/ Project / IPCN). The plants of the whole subfamily Spiraeoideae including meadowsweets are characterized by the main number of chromosomes $\mathrm{n}=9$. The karyotypes of the $S$. betulifolia and the $S$. beauverdiana from the Russian Far East contain 18 chromosomes and are diploids $(2 \mathrm{n}=$ 18) with a base number equal to 9 (Dickson et al. 1992, Zhukova 1980, Polyakova \& Muratova 2015). Probably, the studied Spiraea species are diploids with different nuclear DNA contents. The obtained values of the nuclear DNA content should not be used to establish Spiraea ploidy due to the lack of reliable information on chromosome numbers in the studied specimens. It is planned to count the chromosome number of the plant samples within a study and to identify their relation to the relative DNA content.
Thus, the revealed values of the relative DNA content in Spiraea differ from each other greatly at the high statistical significance $(\mathrm{p}<0.001)$. The relative DNA content in the $S$. betulifolia $(2 \mathrm{C}=0.91$ and $1.01 \mathrm{pg})$ is twice than in the other species. The $S$. beauverdiana $(2 \mathrm{C}=0.55$ and $0.57 \mathrm{pg})$ and the $S$. aemiliana $(2 \mathrm{C}=0.45$ and $0.48 \mathrm{pg})$ are closer in DNA content.

\section{ACKNOWLEDGEMENTS}

This study was conducted with a financial support of the Russian Fund of Basic Research (project № 16-3400106 to Kostikova), and also by the Program of Fundamental Researches of the Presidium of Russian Academy of Sciences № 32 "Evolution of the organic world. The role and influence of planetary processes" (№ 0112-20180027 "The study of genetic mechanisms of evolution at the genomic and organismal level: the role of hybridization, the effects of global environmental change"). While preparing the publication, the materials of the bioresource research collection of the Central Siberian Botanical Garden of SB RAS No. USU 440534 "Collection of living plants in the open and covered ground" were used.

\section{LITERATURE CITED}

Bennett, M.D \& I.J. Leitch 2012. Angiosperm DNA C-values database (release 8.0, Dec. 2012). http:/ / data.kew.org/cvalues $/$ CvalServlet?querytype=2. Last accessed 15.05.2018.

Dickson, E.E., K. Arumuganathan, S. Kresovich \& J.J. Doyle 1992. Nuclear DNA content variation within the Rosaceae. American Journal of Botany 79:1081-1086.

Doležel, J., J. Bartoš, H. Voglmayr \& J. Greilhuber 2003. Nuclear DNA content and genome size of trout and human. Cytometry 51: 127-128

Doležel, J., S. Sgorbati \& S. Lucretti 1992. Comparison of three DNA fluorochromes for flow cytometric estimation of nuclear DNA contrent in plants. Physiologia Plantarum 85: 625-631.

Koropachinskii, I.Yu. \& T.N. Vstovskaya 2002. Woody plants of Asian Russia. Geo, Novosibirsk, 707 pp. (in Russian). [Коропачинский И.Ю., Встовская Т.Н. 2002. Аревесные растения Азиатской России. Новосибирск: Гео. 707 с.].

Kostikova, V.A. \& T.A. Polyakova 2014. Eco-geographical variability of Spiraea betulifolia Pall. and $S$. beauverdiana Schneid. on the morphological and biochemical markers. Contemporary Problems of Ecology 7(3):315-323. 
Leitch, I.J., D.E. Soltis, P.S. Soltis \& M.D. Bennett 2005. Evolution of DNA amounts across land plants (Embryophyta). Annals of Botany 95:207-217.

Marda, P.S., P. Bures, L. Horova, B. Foggi \& G. Rossi 2008 Genome size and GC content evolution of Festuca: ancestral expansion and subsequent reduction. Annals of Botany 101:421-433.

Nedoluzhko, V.A. 1995. Dendroflora compendium of the Russian Far East. Dalnauka, Vladivostok, 208 pp. (in Russian). [Недолужко В.А. 1995. Конспект Аендрофлоры Российского Аальнего Востока. ВАадивосток: Аальнаука. 208 с.].

Oginuma, K., I.V. Tatarenko \& K. Kondo 2004. Karyomorphology of eight species of Spiraea (Rosaceae) in Russia. Chromosome Science 8(1):23-28.

Polyakova, T.A. \& E.N. Muratova 2015. Karyological study of some species of the genus Spiraea (Rosaceae) of the Far Eastern and Eastern Siberian flora. Rastitelnyi mir Aziatskoi Rossii 2(18):23-26. (in Russian with English summary). [Полякова Т.А., Муратова Е.Н. 2015. Кариологическое исследование некоторых видов рода Spiraea (Rosaceae) фцоры Аальнего Востока и Восточной Сибири // Растительный мир Азиатской России. Т. 2, № 18. С. 23-26].

Siljak-Yakovlev, S., F. Pustahija, E.M. Solic, F. Bogunic, E. Muratovic, N. Bašic, O. Catrice \& S.C. Brown 2010 Towards a genome size and chromosome number database of Balkan flora: C-values in 343 taxa with novel values for 242. Advanced Science Letters 3: 190-213.

StatSoft, Inc. (1998). STATISTICA for Windows [Computer program manual]., WEB: http://www.statsoft.com.

Svyazeva, O.A. 1967. Distribution of woody Rosaceae in the USSR (notably a case of the genus Spiraea): $\mathrm{PhD}$ dissertation theses.
Komarov Botanical Garden, Leningrad, 23 pp. (in Russian). [Связева О.А. 1967. Распространение Аревесных розоцветных в СССР (в особенности на примере роАа спирея): автореферат Аис. ... Аокт. био . наук. $\Lambda$ енинграА, Ботан. ин-т им. В.А. Комарова. 23 с.].

Talluri, R.S. \& B.G. Murray 2009. DNA C-values and chromosome numbers in Fuchsia L. (Onagraceae) species and artificial hybrids. New Zealand Journal of Botany 47:33-37.

Tsvelyov, N.N. 2008. On meadowsweet species (Spiraea L., Rosaceae) of the section Calospira C. Koch at the Russian Far East. Novosti sistematiki vysshih rastenii 40:76-83 (in Russian). [Цвелёв Н.H. 2008. О вилах спиреи (Spiraea L., Rosaceae) секции Calospira C. Koch на Аальнем Востоке России // Новости систематики высших растений. Вып. 40. С. 76-83].

Vorobyov, D.P. 1968. Wild trees and bushes of the Far East. A key to species. Nauka, Leningrad, 278 pp. (in Russian). [Воробьев А.П. 1968. Аикорастущие деревья и кустарники Аальнего Востока. Определитель. Аенинград: Наука. 278 с.].

Yakubov, V.V. 1996. The genus Spiraea L. In: Vascular plants of the Soviet Far East, vol. 8, (S.S. Kharkevich, ed.), pp. 130136. Nauka, Saint-Petersburg (in Russian). [Якубов B.B. 1996. Род Таволга - Spiraea L. / / Сосудистые растения Советского Аальнего Востока. Санкт-Петербург: Наука. Т. 8. С. 130-136].

Zhukova, P.G. 1980. Chromosomal numbers of some plant species in South Chukotka. Botanicheskii Zhurnal 65(1):5159 (in Russian). [Жукова П.Г. 1980. Хромосомные чисма некоторых видов растений Южной Чукотки // Ботанический журнал. Т. 65, № 1. С. 51-59]. 